\title{
AFF3 wt Allele
}

National Cancer Institute

\section{Source}

National Cancer Institute. AFF3 wt Allele. NCI Thesaurus. Code C53030.

Human AFF3 wild-type allele is located within 2q11.2-q12 and is approximately $595 \mathrm{~kb}$ in length. This allele, which encodes AF4/FRM2 family member 3 protein, may play roles in both the activation of RNA polymerase II-directed transcription and the development of lymphoid tissues. Acute lymphoblastic leukemia is associated with rearrangement and fusion of this gene to the MLL gene. 